Pure \& Appl. Chem., Vo1. 52, pp.45-53.

Pergamon Press Ltd. 1979. Printed in Great Britain.

\title{
FRACTIONATION AND DETERMINATION OF TRACE ELEMENTS IN PLANTS, SOILS AND SEDIMENTS (*)
}

\author{
A. Cottenie, R. Camerlynck, M. Verloo, A. Dhaese
}

Faculty of Agriculture, State University, Coupure Links 533, B-9000 Gent, Belgium.

\begin{abstract}
With the aid of more sensitive instrumental methods it is possible to determine trace elements after separation of different fractions from soil and plant samples.

Fractions of soils and sediments are obtained by extraction with different reagents, chosen in function of biological, ecological or chemical considerations.

In plant samples it is possible to separate free ions and organo-mineral complexes combining techniques of extraction, sephadex gel filtration and ion exchange, thin layer chromatography, electrophoresis and molecular filtration.
\end{abstract}

\section{INTRODUCTION}

Agricultural and biological research laboratories have a traditional interest for trace element analysis. (14) (15) (18).

Beside molecular absorptiometry and emission spectrometry, there is a choice of electrochemical, neutron activation, spectrofluorimetric, Röntgen fluorimetric and mass spectrometric techniques, while atomic absorption and more recently inductively coupled plasma (ICP) emission spectrometry have known an impressive development.

Several of these methods require a rather heavy instrumentation, while medium size instruments, such as atomic absorptiometers, have been rapidly introduced on a large scale. Judging by the number of publications it seems that electro-analytical methods didn't get the same popularity, though they offer also attractive possibilities. Anodic stripping voltametry (24) is gaining interest and specific electrodes represent an attractive tool at the condition that interferences are carefully corrected or avoided.

The continuous lowering of detection and determination limits has stimulated the study of a new family of trace elements, at the ppb level, in soils and biological material.

One can expect that this tendency will continue, together with an increasing interest for the separation of total contents into fractions of different biological importance and activity. Appropriate methods for such studies are described in this paper.

\section{TRACE ELEMENTS IN SOILS AND SEDIMENTS}

Soil chemical analysis presents different aspects, according to the fractions of elements being considered.

The determination of total trace element contents is mainly used in geochemistry. From an agricultural point of view a biologically active fraction is of more interest. Its determination is based on the solubilization of fractions which are considered as available, accessible, mobile or simply extractable.

More recently, the amounts of trace elements being introduced into the soil, accidentally or intentionally, e.g. with waste products and sludges, are such that total contents also deserve an increased agricultural interest.

The same applies to river sediments, where the distribution of mineral elements between the sediment and the liquid phase is also governed by their mobility. From an ecological point of view it is important that excesses of heavy metals and other toxic elements should be immobilized and retained in the solid phase.

\section{Total soil analysis}

The methods used for total trace analysis are comparable to those applied for minerals, rocks, meteorites and the order of contents of mineral elements in soils are, in ppm :

(*) Research carried out with the aid of the Belgian "Institut pour l'Encouragement de la Recherche Scientifique dans 1'Industrie et 1 'Agriculture (I.R.S.I.A.) Brussels. 


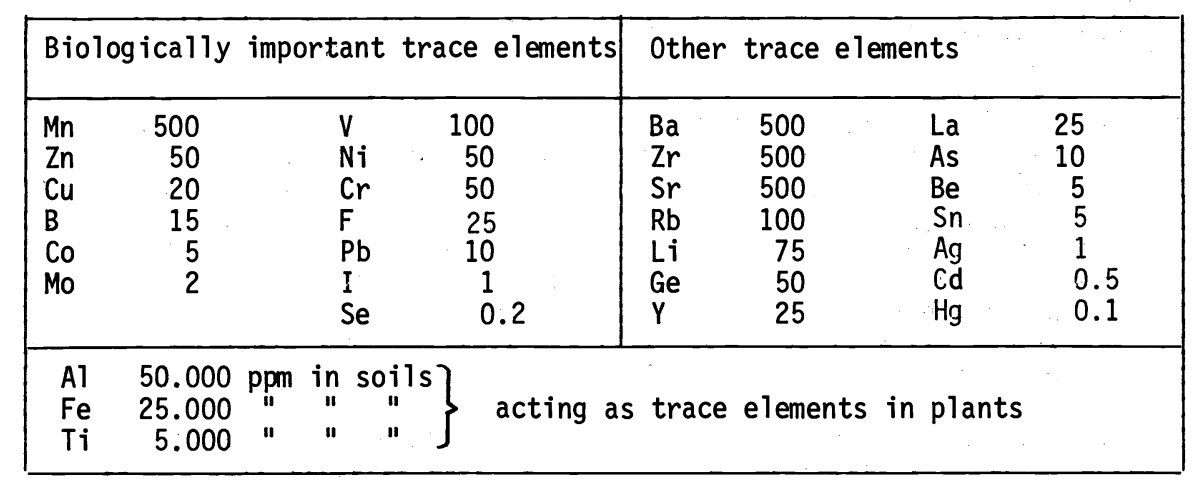

The major problems in total soil analysis are sample pretreatment and preparation of standards sufficiently similar with the samples.

Methods suitable for powder analysis such as arc or spark emission, X-ray fluorescence and spark-source mass spectrometry, permit to reduce sample preparation to a minimum, avoiding contamination. Generally, the finely powdered samples are thoroughly mixed in an agata mortar with a diluent powder, acting at the same time as a buffer, levelling off the differences between samples, reducing inter-element effects, providing a common matrix and containing internal standards (5).

A spark-source mass spectrometric method, capable to provide quantitative determinations of more than 50 elements with a precision of 10 to $15 \%$ by direct soil analysis, was recently described by URE and BACON (23). The samples, mixed with 1 part of pure aluminium powder containing indium and iridium as internal standards, are pelleted and used as electrodes.

For soil analysis, the effects of matrix and granulometric differences can be further reduced through isoformation by fusion of the sample with e.g. lithium tetraborate or a mixture of boric acid, lithium and strontium carbonates. This procedure entails however a dilution, which affects the sensitivity.

The problem of isoformation is of course inexistant after solubilization of the soil samples. This requires fusion with sodium carbonate (15) or borate and implies an important dilution. Therefore such techniques represent generally the first step of chemical concentration procedures, e.g. producing concentrates in an alumina matrix after precipitation of trace elements with 8-hydroxyquinoline, tannic acid and thionalide (thioglycol B-amino-naphthalide) (23). other concentration techniques make use of sulphide-precipitation (7) or complexation with ammonium pyrrolidine dithio carbamate and chloroform extraction (11).

The mentioned concentration methods result in the elimination of major constituents and a several 100-fold enrichment.

\section{Extractible fractions}

A large number of methods have been described for the extraction of trace elements, either individually or simultaneously. Their value is judged in function of more or less satisfying correlations between the extracted amounts and plant uptake or growth response. The large number and diversity of methods indicates by itself their speculative character.

Only for a few elements there is sufficient agreement on one common method. Thus boron is generally extracted with hot water (2) and molybdenum with neutral ammonium acetate (15) or ammonium oxalate at $\mathrm{pH} 3.3$ (8). In the case of manganese, the method of SCHACHTSCHABEL (19), distinguishing between soluble, exchangeable, easily reducible and active fractions by different successive treatments, has been largely adopted.

For simultaneous extraction of trace elements, ammonium acetate at $\mathrm{pH} 4.8$ has often been employed. LAKANEN introduced an extraction with $0.5 \mathrm{n}$ ammonium acetate, containing $0.02 \mathrm{~m}$ EDTA at $\mathrm{pH} 4.65$ (12). The presence of EDTA prevents precipitation of several trace elements with phosphates, which might take place as a secondary reaction during soil extraction. Chelating agents, especially DTPA (diethylene-triamine-penta-acetic acid), are increasingly used and LINDSAY and NORVELL (13) proposed $0.005 \mathrm{~m} \mathrm{DTPA}, 0.01 \mathrm{~m} \mathrm{CaCl} 2$ and $0.1 \mathrm{~m} \mathrm{TEA} \mathrm{(tri-}$ ethanol amine) as an extractant.

An interesting new extracting solution containing $0.005 \mathrm{~m} \mathrm{DTPA}$ in $1 \mathrm{~m} \mathrm{NH} \mathrm{HCO}_{3}$ at $\mathrm{pH} 7.6$, was recently added to the existing list by SOLTANPOUR and SCHWAB (21). A more general review of the problems involved in estimating the micronutrient status of soils was made by SILLANPÄA (20).

In routine analysis the principle techniques of generalized use are : flame atomic absorption for $\mathrm{Fe}, \mathrm{Mn}, \mathrm{Zn}, \mathrm{Cu}, \mathrm{Co}$; flameless atomic absorption for $\mathrm{Mo}, \mathrm{Al}, \mathrm{Hg}, \mathrm{Cd}, \mathrm{Pb}$; spectrophotometry for B, As ; spectrofluorimetry for Al, Se; specific electrodes for $F$.

The elements $\mathrm{Sn}, \mathrm{Sb}, \mathrm{Se}, \mathrm{Br}$ and others still form a difficult group from the trace analytical point of view. The recommended method for bromide is neutron activation as well as a gaschromatographic determination after linking as methylbromide and electron capture detection. The new possibilities offered by ICP emission spectrometry are rapidly being explored. 
Meanwhile, more fundamental studies concern the mechanisms of extracting fractions of trace elements, based on phase equilibria.

When a soil or sediment sample is put in contact with a solution, the system tends to an equilibrium in which the total amount of an element $M$ is distributed over free, complexed, adsorbed and solid forms, in function of equilibrium constants and solubility products and resulting from different competitive reactions in which all components take part. In the liquid phase trace elements are present as free ions and as soluble organo-mineral complexes. Changing $\mathrm{pH}$ and redox-potential may cause important equilibrium displacements. Furthermore "suspended solids" may contribute to an increased content of adsorbed trace elements in the liquid phase, where they form a "pseudo-solution". This accounts greatly for the presence of heavy metals in rivers.

Working on the soil sample itself, the following fractions may be separated :

a) the amount soluble in water or in any other extracting solution. As a rule only a small part of trace elements is soluble in water, while an important fraction dissolves in strong acid medium.

KRÄHMER and BERGMANN (10) distinguished the following copper fractions :

Cu-org : soluble in NaOH/EDTA

$\mathrm{Cu}-0 \mathrm{x}$ : soluble in Am-oxalate-oxalic acid

$\mathrm{Cu}-\mathrm{occl}$ : (occluded with Fe-oxides) soluble in Am-oxalate-oxalic acid containing zinc $\mathrm{Cu}-\mathrm{Si}:$ soluble in hot perchloric acid

and found that they were principally determined by the geological origin of the soil. $\mathrm{Cu}$-org and $\mathrm{Cu}-\mathrm{ox}$ were narrowly correlated with the $0.43 \mathrm{n} \mathrm{HNO}_{3}$ extractable fraction.

ANDERSSON (1) made an attempt to separate ecologically significant fractions of heavy metals in soils by means of three common soil extractants : $2 \mathrm{~m} \mathrm{HNO}$ at $100^{\circ} \mathrm{C}(2 \mathrm{~h}$ in a boiling waterbath), $1 \mathrm{~m} \mathrm{NH}_{4} \mathrm{OAC}$ at $\mathrm{pH} 4.8$ and 7 respectively (at $20^{\circ} \mathrm{C}$ in an end-over-end rotator for $1 \mathrm{~h}$ ).

With $1 \mathrm{~m} \mathrm{NH}_{4} \mathrm{OAC}$ at $\mathrm{pH} 4.8$ the most mobile fractions are separated.

Extraction with $2 \mathrm{~m} \mathrm{HNO}_{3}$ proved to release an important percentage (57-92\%) of the total content of the different heavy metals, so that it gives valuable information on the total pollution with these elements.

A method for evaluating the potentially mobile fraction of trace elements consists in preparing a soil-water suspension (ratio 1/10) and stepwise acidifying with $\mathrm{HNO}_{3}$ from the original pH till pH 0.5 . After equilibration during 1 hour the liquid phase is separated by filtration and analyzed. This gives typical mobilization patterns as shown in table 1.

b) exchangeable ions are obtained by percolation or extraction with a solution containing a displacing ion, neutral $1 \mathrm{~m}$ or $0.5 \mathrm{~m} \mathrm{NH}_{4} \mathrm{OAC}$ frequently being used.

c) trace elements linked with organic matter can be extracted with $0.2 \mathrm{n} \mathrm{NaOH}(\mathrm{pH} 12)$. A further separation is possible by bringing the extract to $\mathrm{pH} 1$ with $\mathrm{HCl}$, which precipitates humic acids, while fulvic acids remain soluble.

The possible influence of organic matter on the behaviour of trace elements in soils is illustrated in fig. 1, showing the different forms of $\mathrm{Cu}$ and $\mathrm{Zn}$ in presence of humic acid at varying $\mathrm{pH}$ values (25).
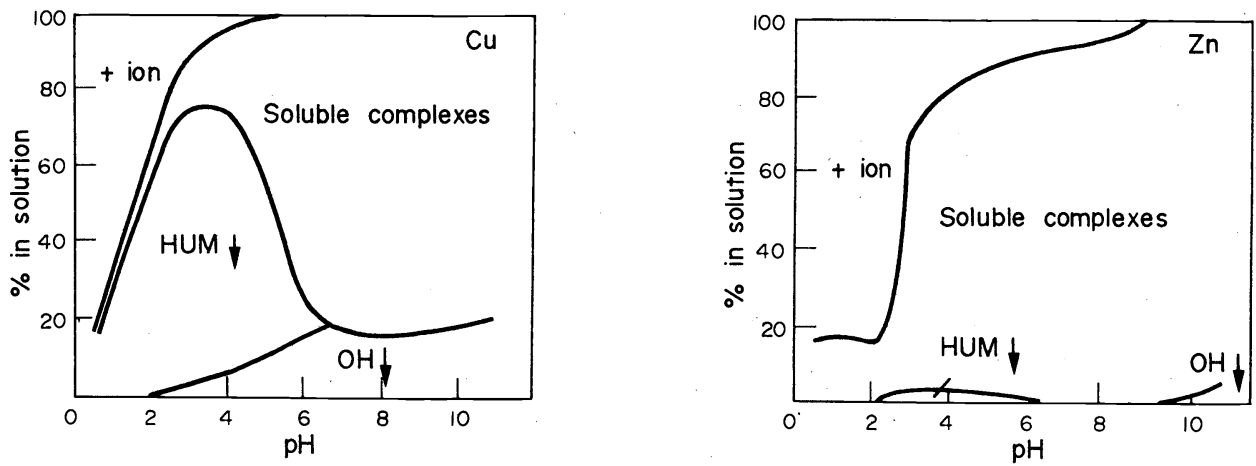

Fig. 1. Percentic distribution of $\mathrm{Cu}$ and $\mathrm{Zn}$ in presence of humic acid

In a soil solution or extract the separation of free and complexed forms of trace elements may be carried out as follows :

1.- - treatment of the solution containing free ions $\mathrm{M}^{+}$and complexes $\mathrm{ML}$, with a cation exchanger $R$ which links the free ions as MR. In practice extracts are treated with $\frac{\overline{2}}{\mathrm{~g}} \overline{\mathrm{D}} \mathrm{\overline {w }} \mathrm{e} \overline{\mathrm{x}}$ $50 \mathrm{~W}$ in $\mathrm{Na}$-form and filtered after one hour. 
Repeating this after destruction of the organic matter by oxidation permits to calculate the following distribution coefficients :

- in presence of organic ligands : $\lambda=\frac{(M R)}{\left(M^{+}\right)+(M L)}$

- in absence of organic ligands : $\lambda_{0}=\frac{(M R)}{\left(M^{+}\right)}$

The complexed fraction is found as $\% M L=\left(1-\frac{\lambda}{\lambda_{0}}\right) \cdot 100$

2. - Another possibility for separating organo-mineral complexes is the use of membrane filters, by which compounds with a molecular weight of 1000 or more can be removed. Trace- eTement analysis of the filtered solutions showed that the organo-mineral complexes have generally high molecular weights. In acid medium however the contribution of such complexes to the solubility of heavy metals decreases rapidly (4).

3. - Separation of the organic fractions in soil extracts is also possible with sephadex-gel filtration. Analys is of the eluted fractions which contain organic compounds indicated by $\bar{U} . \bar{V}$. detection $(265 \mathrm{~nm})$, permits to identify the presence of $\mathrm{Cu}, \mathrm{Zn}$, etc. in complexed forms. This necessitates of course highly sensitive analytical methods e.g. flameless atomic absorption.

4. - Specific electrodes are an attractive tool for determining the chemical activity of ions such as $\mathrm{Cu}^{++}$and $\mathrm{Cd}++$ in the liquid phase of the soil. With this technique it was possible to observe the evolution of added elements, which rapidly decreased in function of adsorption and complexing mechanisms.

Table 1. Mobilization patterns of trace elements in soils in function of acidity (mg per $\mathrm{kg}$ soil)

\begin{tabular}{|ll|c|c|c|c|c|c|c|c|c|}
\hline $\begin{array}{l}\text { pH of soil } \\
\text { suspension }\end{array}$ & $\mathrm{Fe}$ & $\mathrm{Mn}$ & $\mathrm{Zn}$ & $\mathrm{Cu}$ & $\mathrm{Co}$ & $\mathrm{Pb}$ & $\mathrm{Cd}$ & $\mathrm{Ni}$ & $\mathrm{Cr}$ \\
\hline normal & 5.7 & 6.7 & $\mathrm{tr}$ & 0.1 & $\mathrm{tr}$ & $\mathrm{tr}$ & $\mathrm{tr}$ & $\mathrm{tr}$ & $\mathrm{tr}$ & $\mathrm{tr}$ \\
soi1 & 4 & 8.4 & 2.4 & 2.2 & $\mathrm{tr}$ & $\mathrm{tr}$ & $\mathrm{tr}$ & $\mathrm{tr}$ & $\mathrm{tr}$ & $\mathrm{tr}$ \\
& 2 & 12 & 24 & 15 & 5.8 & 0.1 & 0.4 & 0.2 & 0.6 & $\mathrm{tr}$ \\
& 0.5 & 778 & 99 & 22 & 14 & 0.5 & 9.6 & 0.3 & 1.0 & 0.7 \\
\hline pol1uted & 6.1 & 2 & $\operatorname{tr}$ & 0.2 & 1.0 & 1.5 & $\operatorname{tr}$ & $\mathrm{tr}$ & $\mathrm{tr}$ & 0.1 \\
soi1 & 4 & 28 & 3.4 & 56 & 98 & 108 & 1.7 & 1.4 & 1.7 & 0.4 \\
& 2 & 1300 & 29 & 272 & 1430 & 995 & 183 & 5.2 & 183 & 35 \\
& 0.5 & 11080 & 88 & 410 & 2445 & 1700 & 530 & 7.1 & 530 & 156 \\
\hline
\end{tabular}

The distribution of heavy metals over different forms in a contaminated soil and in a river sediment, is shown in table 2.

Table 2. Different forms of trace elements in soil and sediment (mg per $\mathrm{kg}$ )

\begin{tabular}{|c|c|c|c|c|c|c|c|c|}
\hline $\begin{array}{l}\text { contaminated } \\
\text { soil }\end{array}$ & Mn & $\mathrm{Zn}$ & $\mathrm{Cu}$ & Co & $\mathrm{Pb}$ & $\mathrm{Cd}$ & $\mathrm{Ni}$ & $\mathrm{Cr}$ \\
\hline $\begin{array}{l}0.5 \mathrm{n} \mathrm{HNO}_{3} \\
\text { extractable } \\
\text { water soluble } \\
\text { adsorbed } \\
\text { complexed } \\
\text { precipitated }\end{array}$ & $\begin{array}{l}82 \\
\operatorname{tr} \\
1.9 \\
0.2 \\
80\end{array}$ & $\begin{array}{c}435 \\
0.2 \\
14 \\
10 \\
319\end{array}$ & $\begin{array}{r}2425 \\
0.7 \\
283 \\
120 \\
2021\end{array}$ & $\begin{array}{c}1650 \\
0.7 \\
23 \\
12 \\
1614\end{array}$ & $\begin{array}{r}658 \\
\operatorname{tr} \\
5.5 \\
8.5 \\
644\end{array}$ & $\begin{array}{l}6.8 \\
\operatorname{tr} \\
1.1 \\
0.1 \\
5.6\end{array}$ & $\begin{array}{l}97 \\
\operatorname{tr} \\
1.1 \\
0.7 \\
95\end{array}$ & $\begin{array}{r}146 \\
0.1 \\
0.6 \\
4.0 \\
141\end{array}$ \\
\hline \multicolumn{9}{|l|}{ river sediment } \\
\hline $\begin{array}{l}0.5 \mathrm{n} \mathrm{HNO}_{3} \\
\text { extractable } \\
\text { water soluble } \\
\text { adsorbed } \\
\text { complexed } \\
\text { precipitated }\end{array}$ & $\begin{array}{c}205 \\
3.7 \\
30 \\
3.3 \\
168\end{array}$ & $\begin{array}{l}509 \\
7.6 \\
24 \\
22 \\
455\end{array}$ & $\begin{array}{l}34 \\
\operatorname{tr} \\
0.2 \\
10 \\
24\end{array}$ & $\begin{array}{l}3.8 \\
0.1 \\
0.1 \\
0.2 \\
3.4\end{array}$ & $\begin{array}{l}88 \\
\operatorname{tr} \\
1.2 \\
2.7 \\
84\end{array}$ & $\begin{array}{l}2.6 \\
\operatorname{tr} \\
0.2 \\
0.1 \\
2.3\end{array}$ & $\begin{array}{l}9.9 \\
0.2 \\
0.3 \\
1.2 \\
8.2\end{array}$ & $\begin{array}{l}41 \\
0.1 \\
5.0 \\
19 \\
17\end{array}$ \\
\hline
\end{tabular}

tr: traces 


\section{TRACE ELEMENTS IN PLANTS}

\section{Uptake and concentration ranges}

The elements $\mathrm{Fe}, \mathrm{Mn}, \mathrm{Zn}, \mathrm{B}, \mathrm{Cu}$ and Mo are essential nutrients for all plants, but many more elements are taken up as well if they are present in an available form in the soil. The content levels of some elements in the dry matter are as follows :
$100 \mathrm{ppm}$ range : $\mathrm{Fe}, \mathrm{Mn}, \mathrm{Zn}, \mathrm{A}$
$10 \mathrm{ppm}$ range : $\mathrm{Cu}, \mathrm{B}, \mathrm{Zn}$
$1 \mathrm{ppm}$ range : Mo, $\mathrm{Co}, \mathrm{Pb}, \mathrm{Ni}, \mathrm{Cr}, \mathrm{Sb}$
$0.1 \mathrm{ppm}$ range : $\mathrm{Cd}, \mathrm{Hg}, \mathrm{Se}, \mathrm{F}$
$<0.1 \mathrm{ppm}$ range : Cd, As, Sn

When the available amounts in the growth medium increase the uptake of various mineral elements follows quite different patterns. The following situations may be distinguished :

a. - large concentration increase in plant tissue for the elements $\mathrm{Zn}, \mathrm{B}, \mathrm{Mo}, \mathrm{Co}, \mathrm{Cd}, \mathrm{Ni}$, which are easily taken up,

b. - limited concentration variations of the elements $\mathrm{Cu}, \mathrm{Pb}, \mathrm{Cr}$,

c.- concentration variations in plant tissue more influenced by $\mathrm{pH}$ and redox potential of the growth medium than by its concentration for $\mathrm{Fe}, \mathrm{Mn}, \mathrm{Al}$.

The corresponding internal concentration ranges indicate successively a deficiency situation, normal contents and phytotoxicity. Experiments with raygrass as an indicator plant gave the following trace element ranges, as ppm in dry matter :

\begin{tabular}{|ll|c|c|c|}
\hline & & deficiency & $\begin{array}{c}\text { normal } \\
\text { range }\end{array}$ & $\begin{array}{c}\text { phytotoxic } \\
\text { contents }\end{array}$ \\
\hline Essential & $\mathrm{Fe}$ & $<50$ & $50-250$ & - \\
elements & $\mathrm{Mn}$ & $<20$ & $25-250$ & $>500$ \\
& $\mathrm{Zn}$ & $<20$ & $25-150$ & $>400$ \\
& $\mathrm{~B}$ & $<10$ & $18-30$ & $>190$ \\
& $\mathrm{Cu}$ & $<5$ & $6-15$ & $>20$ \\
& $\mathrm{Mo}$ & 0.1 & $0.5-5$ & - \\
\hline Non essential & $\mathrm{Pb}$ & - & $2-14$ & - \\
elements & $\mathrm{F}$ & - & $5-8$ & $>50$ \\
& $\mathrm{Ni}$ & - & $0-8$ & $>80$ \\
& $\mathrm{Co}$ & - & $0-2$ & $>100$ \\
& $\mathrm{Cd}$ & - & $0-0.5$ & $>100$ \\
& $\mathrm{Cr}$ & - & $0-0.5$ & $>2$ \\
\hline
\end{tabular}

\section{Analytical methods}

Generally the determination of trace elements in plants starts with the so-called "mineralization" step. This is a complete desintegration of the organic matter either by ashing or by wet destruction with boiling acid mixtures.

Due to the differences in plant composition, the elements to be determined are present in largely varying matrices. Normally synthetic standards of different basic composition are prepared for calibration in similar conditions. Natural standards composed of different species samples, carefully analyzed by a number of cooperating laboratories have also been prepared for calibration tests (17).

\section{Trace element fractions and distribution}

Relatively little is still known about the forms in which trace elements occur in plants, though their biological activity is mainty determined by the chemical form. It is evident that they may partly be present as free ions and partly incorporated in organo-mineral compounds.

Chelation prevents precipitation and keeps trace cations soluble during translocation.

TIFFIN (22) showed that citrate acts as a chelator for $\mathrm{Fe}^{+++}$in different plants. HóFNER (9) found that $\mathrm{Fe}, \mathrm{Mn}, \mathrm{Zn}, \mathrm{Co}$ and $\mathrm{Ni}$ are partially chelated and transported by amino acids and peptides and it is probable that also sugars, phenols and hydroxy-acids act in the same way. On the other hand metallic ions are known to act as cofactors or activators in enzyme systems and more than $25 \%$ of all known enzymes belong to the metalloenzyme group.

Application of highly resolving separation methods in combination with sufficiently sensitive analytical techniques makes now possible to study the distribution and incorporation of trace elements in biological samples. Such methods and results are described in the following paragraphs. 


\section{Analytical procedures}

Combining methods of extraction, sephadex gel filtration and ion exchange, thin layer chromatography, electrophoresis and molecular filtration it is possible to compose an analytical chain for separating free ions and organomineral complexes in plant samples. The general scheme of the analytical system is shown in fig. 2.

Fresh plant material is smashed under liquid nitrogen in order to stop any enzymatic activity and 5 to $10 \mathrm{~g}$ of the fine ground sample are homogenized with a high speed blender in 50 to 100 $\mathrm{ml}$ bidistilled water. The suspension is centrifuged for 30 minutes and the supernatant liquid filtered through a $0.45 \mu$ membrane filter. This solution is used for further separations.

Figure 2. Analytical scheme for fractionation of trace elements in plant tissues

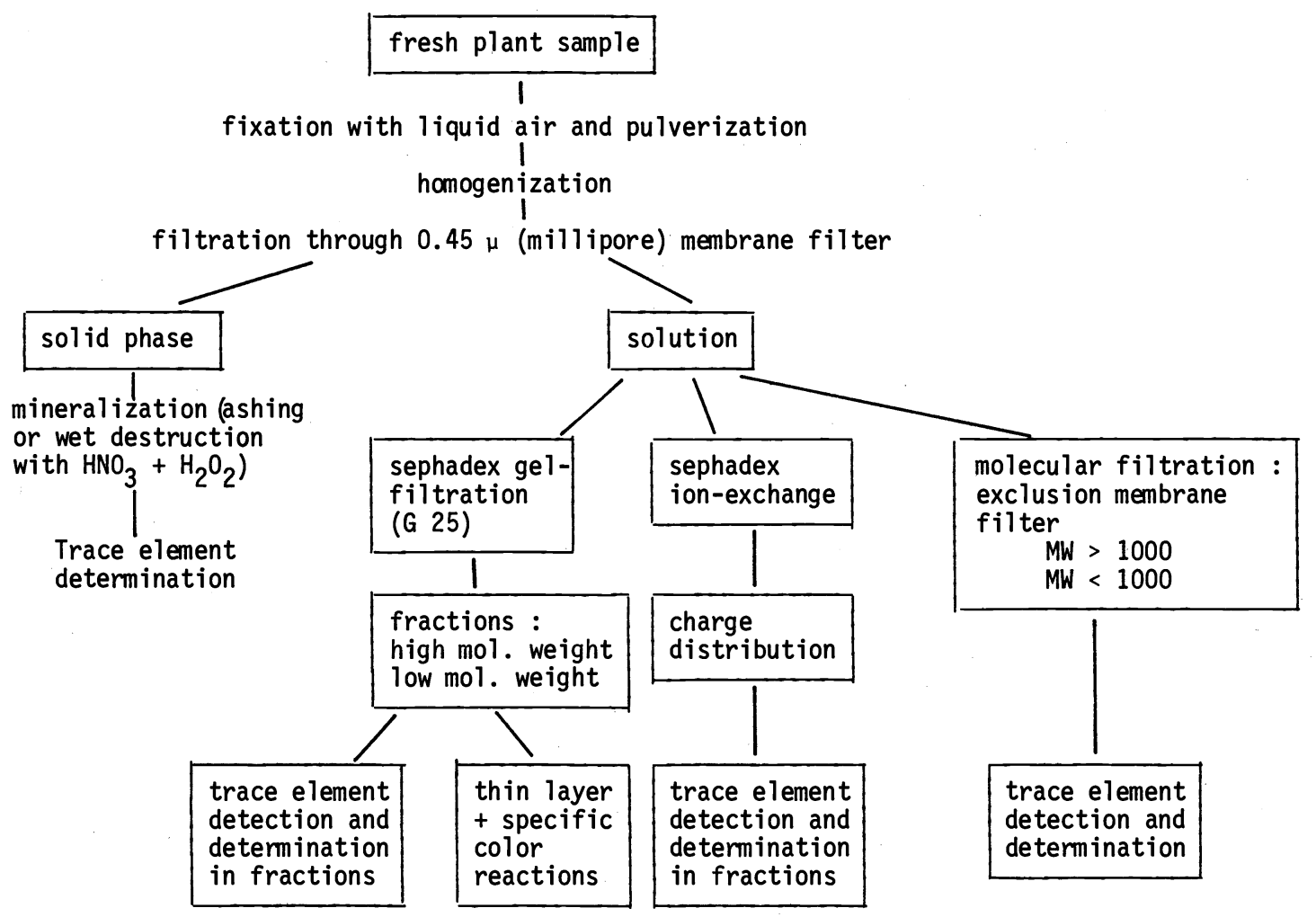

electrophoresis : general use possible at each step

\section{Separations based on molecular weight differences}

An aliquot of the tissue extract $(5-10 \mathrm{ml})$ is carefully put on a column filled with sephadex G-25 (diameter $3 \mathrm{~cm}$, length $90 \mathrm{~cm}$ ) and eluted with a $\mathrm{NaOAc}-\mathrm{HOAc}$ buffer of $\mathrm{pH} 6$. The solution obtained after the void volume (Vo) is collected in fractions of $5 \mathrm{ml}$ until a total of at least two times the bed volume. The trace element content of each fraction is determined using a sufficiently sensitive method e.g. flameless atomic absorption.

These concentrations are plotted against the eluted volume and for comparison superposed on analogous histograms obtained with free ion solutions treated in a similar way.

At the same time each fraction is spotted on a thin layer and specific color reactions e.g. with ninhydrin for amino-acids are used to identify the nature of the yielded compounds: amino acids, peptides, sugars, phenols etc.

As an exemple figure 3 shows the presence of copper, which is found in complexes, corresponding with the peaks 1 and 2 (dotted curve). If any free copper had been present, it should have been located in correspondance with peak 4, which shows the elution of Cu2t at pH 6 , and peak 3 at $\mathrm{pH} 3$. This experiment indicates that the total amount of copper is incorporated in two complexes, one high molecular weight fraction (M.W. > 5000) and another main fraction with a molecular weight slightly higher than 1000. Both complexes furthermore proved to be aminoacids or peptides bearing negative charges. 
Analogous experiments show that an important fraction of zinc in plant tissue is present in free ionic form.
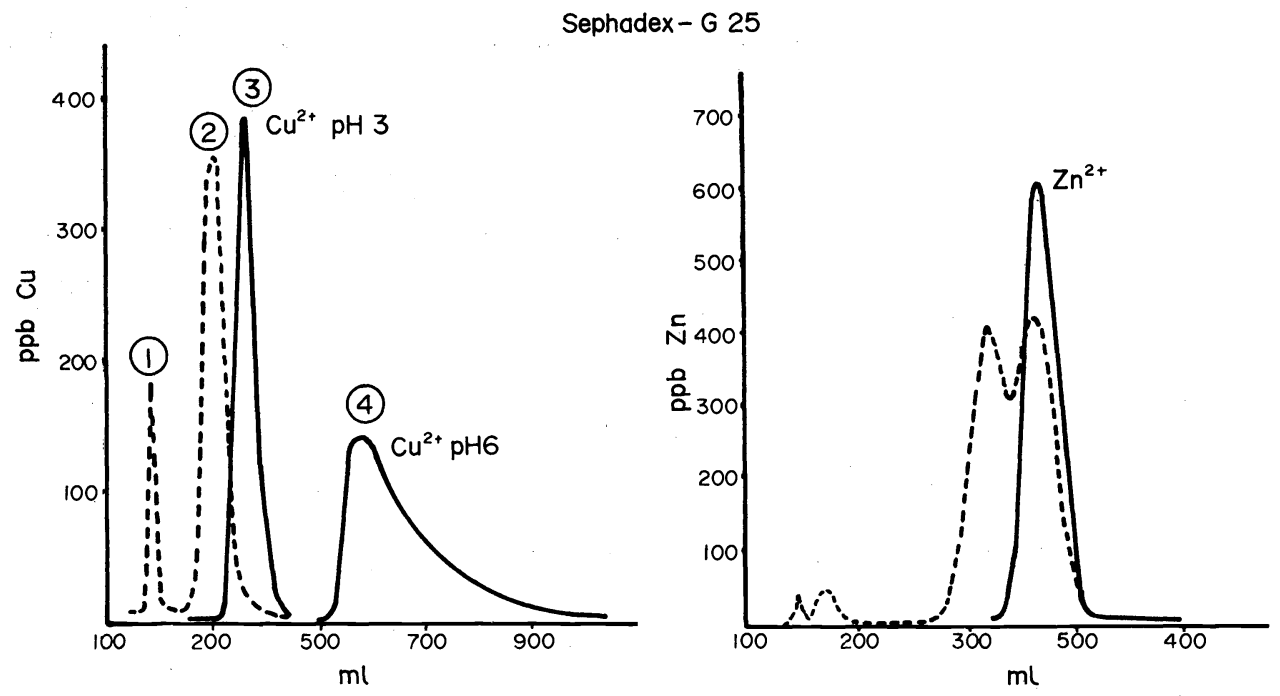

Fig. 3. Separation of $\mathrm{Cu}-$ and $\mathrm{Zn}$-complexes by Sephadex gel filtration (--- complexes free ions).

\section{Separations based_on charge_differençes}

Ion exchange and electrophoresis are also appropriate methods for separation of free and complexed forms of trace elements in plants.

In our experiments 5 to $10 \mathrm{ml}$ of the tissue extracts are brought upon columns (diameter $4 \mathrm{~cm}$, height $10 \mathrm{~cm}$ ) containing $75 \mathrm{ml}$ of the following sephadex ion exchanging gels : cation exchanger CM-C 25, anion-exchanger DEAE A-25 and a combination of both. Elution is carried out respectively with the NaOAC-HOAC-buffer (CM-C25) and with $0.1 \mathrm{n} \mathrm{NaCl}$ (DEAE A-25 ml and combined column).

The element under study is quantitatively determined in the yielded solutions, if necessary after previous concentration. Taking into account its presence as a cation ( $M^{+}$) and in anionic $\left(i^{-}\right)$, amphoteric $\left(M^{ \pm}\right)$and neutral $\left(M^{\circ}\right)$ complexes, the total quantity is

$$
\Sigma M=M^{+}+M^{-}+M^{+}+M^{\circ}
$$

The following information results from the experimental data and permits to calculate the value of each component.

$\begin{array}{lll}\text { anion exchanger } & \frac{\text { retained }}{M^{-}+M^{ \pm}} & \frac{\text { not retained }}{M^{+}+M^{\circ}} \\ \text { cation exchanger } & M^{+}+M^{ \pm} & M^{-}+M^{\circ} \\ \text { mixture of both } & M^{+}+M^{-}+M^{ \pm} & M^{\circ}\end{array}$

Experimental results obtained for copper, zinc and lead are summarized in table 3 .

Table 3 . Fractionation of $\mathrm{Cu}, \mathrm{Zn}$ and $\mathrm{Pb}$ in plant extract with sephadex ion exchanger

\begin{tabular}{|c|c|c|c|c|c|c|}
\cline { 2 - 7 } \multicolumn{1}{c|}{} & \multicolumn{2}{c|}{$\mathrm{cu}$} & \multicolumn{2}{c|}{$\mathrm{Pb}$} \\
\cline { 2 - 7 } & $\begin{array}{l}\text { ppm in } \\
\text { solution }\end{array}$ & $\%$ & $\begin{array}{l}\text { ppm in } \\
\text { solution }\end{array}$ & $\%$ & $\begin{array}{l}\text { ppm in } \\
\text { solution }\end{array}$ & $\%$ \\
\hline$M^{+}$ & 5.34 & 100 & 10.26 & 100 & 0.49 & 100 \\
$M^{-}$ & 0.08 & 1.5 & 7.16 & 69.8 & 0.10 & 20.4 \\
$M^{ \pm}$ & 2.58 & 48.3 & 0.8 & 7.8 & $0 .-$ & $0 .-$ \\
$M^{\circ}$ & 1.88 & 35.2 & 0.4 & 3.9 & 0.10 & 20.4 \\
\hline
\end{tabular}

These observations are in agreement with the results obtained by gel filtration. They confirm that copper is almost completely complexed $(98.5 \%)$ and so are some $30 \%$ of zinc and $80 \%$ of lead.

Paper electrophoresis may also be used at different stages of the analytical scheme. Therefore $2 \mathrm{ml}$ solution are applied in a thin strip of about $0.5 \mathrm{~cm}$ on electrophoretic paper saturated 
with the same NaOAc-buffer of $\mathrm{pH} 6$ as used for sephadex gel filtration.

A potential of $10 \mathrm{~V}$ per $\mathrm{cm}$ is applied over $35 \mathrm{~cm}$ length during 120 minutes and the paper is then dried at $110^{\circ} \mathrm{C}$. Strips of $1 \mathrm{~cm}$ are cut and eluted with boiling $0.1 \mathrm{n} \mathrm{HNO}_{3}$ for elementary analysis (15 strips at anode side and 15 strips at cathode side).

\section{ANALYTICAL SENSITIVITY AND PRECISION}

Though the sensitivities of various analytical methods are often very different for the individual elements, the determination limits are situated between : $10^{-4}$ and $10^{-2} \mathrm{ppm}$ (neutron activation, stripping voltametry, flameless atomic absorption), $10^{-3}$ and $10^{-1} \mathrm{ppm}$ (ICPemission spectrometry), $10^{-2}$ and $10^{\circ} \mathrm{ppm}$ (flame atomic absorption, molecular absorptiometry), $10^{-1}$ and $10^{\circ} \mathrm{ppm}$ (spark source mass spectrometry) and > $1 \mathrm{ppm}$ (X-ray fluorescence).

In order to make sure that a significant analytical difference between two mean values should correspond with a biologically significant difference, COTTENIE e.a. (6) have estimated the maximum allowable standard error $\sigma$, permitting to detect a given significant difference $\delta$ between two samples (see table 4 ).

Table 4. maximum allowable standard error $\sigma$ for detecting a given difference $\delta$ (*)

\begin{tabular}{|c|c|c|c|c|c|c|c|c|c|c|c|c|}
\hline \multirow{2}{*}{$\begin{array}{l}\text { Difference } \\
\delta \text { to be } \\
\text { detected }\end{array}$} & \multicolumn{6}{|c|}{ significance level $p_{1}=0.05$} & \multicolumn{6}{|c|}{ significance level $p_{1}=0.01$} \\
\hline & $P=0.80$ & $\begin{array}{c}n=2 \\
P=0.90\end{array}$ & $P=0.95$ & $P=0.80$ & $\begin{array}{c}n=3 \\
P=0.90\end{array}$ & $P=0.95$ & $P=0.80$ & $\begin{array}{c}n=2 \\
P=0.90\end{array}$ & $P=0.95$ & $P=0.80$ & $\begin{array}{c}n=3 \\
P=0.90\end{array}$ & $P=0.95$ \\
\hline $\begin{array}{r}\text { ppm } \\
50 \\
25 \\
20 \\
10 \\
5 \\
4 \\
2 \\
1 \\
0.1\end{array}$ & $\begin{array}{c}12.56 \\
6.280 \\
5.024 \\
2.512 \\
1.256 \\
1.005 \\
0.502 \\
0.251 \\
0.025\end{array}$ & $\begin{array}{c}10.40 \\
5.202 \\
4.161 \\
2.081 \\
1.040 \\
0.832 \\
0.416 \\
0.208 \\
0.021\end{array}$ & $\begin{array}{l}8.561 \\
4.281 \\
3.425 \\
1.712 \\
0.856 \\
0.685 \\
0.342 \\
0.171 \\
0.017\end{array}$ & \begin{tabular}{|c|}
19.93 \\
9.964 \\
7.971 \\
3.985 \\
1.993 \\
1.594 \\
0.797 \\
0.399 \\
0.040
\end{tabular} & $\begin{array}{c}16.71 \\
8.354 \\
6.683 \\
3.342 \\
1.671 \\
1.337 \\
0.668 \\
0.334 \\
0.033\end{array}$ & \begin{tabular}{|c|}
14.36 \\
7.181 \\
5.744 \\
2.872 \\
1.436 \\
1.149 \\
0.574 \\
0.287 \\
0.029
\end{tabular} & $\begin{array}{l}6.230 \\
3.115 \\
2.492 \\
1.246 \\
0.623 \\
0.498 \\
0.249 \\
0.125 \\
0.012\end{array}$ & $\begin{array}{l}5.649 \\
2.824 \\
2.260 \\
1.130 \\
0.564 \\
0.452 \\
0.226 \\
0.113 \\
0.011\end{array}$ & $\begin{array}{l}5.058 \\
2.529 \\
2.033 \\
1.011 \\
0.506 \\
0.405 \\
0.202 \\
0.101 \\
0.010\end{array}$ & $\begin{array}{r}13.06 \\
6.531 \\
5.225 \\
2.612 \\
1.306 \\
1.045 \\
0.522 \\
0.261 \\
0.026\end{array}$ & \begin{tabular}{|c}
11.60 \\
5.799 \\
4.639 \\
2.320 \\
1.160 \\
0.928 \\
0.464 \\
0.232 \\
0.023
\end{tabular} & \begin{tabular}{|c}
10.42 \\
5.208 \\
4.166 \\
2.083 \\
1.042 \\
0.833 \\
0.417 \\
0.208 \\
0.021
\end{tabular} \\
\hline
\end{tabular}

(*) The $\sigma$ values are given with 4 significant figures

P : probability

\section{INTERNATIONAL PROGRAMS}

The most important problems with regard to trace elements are jointly studied by the members of the F.A.O. European research network on trace elements. A comparative study of analytical diagnosis of soils and plants aims to agree on a common reference method. Besides analytical problems,calibration and interpretation studies are also carried out, while the cycling of trace elements and the importance of airbornetrace elements towards agricultural crops and arable land are also estimated.

\section{CONCLUSIONS}

The separation techniques described, in combination with sufficiently sensitive analytical methods, permit to study the behaviour of trace elements in plants, soils and sediments. This makes possible to judge the nutrient and ecological situation of soils and sediments, to observe in which way eventual excesses are stored in plant tissues and to study the incorporation of essential as well as non essential trace elements in plants. The proportions in which free ions, organomineral complexes and adsorbed forms are present vary largely from one element to another. 


\section{REFERENCES}

1. A. Andersson, Swedish J. Agric. Res., 6, p. 19-25 (1976)

2. K. Berger \& E. Truog, Ind. Eng. Chem., Anal. Ed., 11, p. 540 (1939)

3. A. Cottenie \& R. CamerTynck, Publ. Kon. Acad. Van België, Brussel (1979)

4. A. Cottenie \& A. Dhaese, Med. Fac. Landb.wet., Gent, 43, p. 1547-1558 (1978)

5. A. Cottenie \& M. Verloo, 8e Colloque sur T'analyse de Ta matière, p. 277-282, Philips, Milano (1969)

6. A. Cottenie e.a., 3e Coll. Intern. sur le Contrôle de l'Alimentation des Plantes Cultivées, Budapest, p. 47-57 (1972)

7. A. Danielsson, XIII Col1. Spectrosc. Intern., Ed. A. Hilger, London, p. 311 (1967)

8. J.L. Grigg, New Zealand J. Sci. Technol., A 34, p. 405 (1953)

9. W. Höfner, Habil. Schrift, Giessen (1969)

10. R. Krähmer \&W. Bergmann, Arch. Acker. u. Pflanzenbau u. Bodenkd., Berlin, 22, 7, S. 405415 (1978)

11. E. Lakanen, Annales Agricult. Fennine, 1, p. 109 (1962)

12. E. Lakanen \& R. Ervio, Acta Agr. Fenn. I23, p. 223-232 (1971)

13. W.L. Lindsay \& W.A. NorveTT, Agron. Abstr., 69, 84 (1969)

14. H. Lundegardh, Die quantitative Spektralanalyse der Elemente, G. Fischer, Jena (1929)

15. R.L. Mitche11, SoiT Sci. Techn. Comm. no 44 (1948)

16. R.L. Mitchel1, XV Coll. Spectrosc. Intern. Plenary Conferences, Madrid, p. 11-23 (1969)

17. M. Pinta, Analusis, 3, no 6, p. 345-353 (1975)

18. M. Pinta, Modern Methods for trace element analysis, Ann Arbor Science, Mich. (1978)

19. P. Schachtschabel, VI Intern. Congres Soil Sci., Paris, 113 (1956)

20. M. Sillanpää, F.A.0. Soils Bulletin $n^{\circ} 17$ (1972)

21. P.N. Soltanpour \& A.P. Schwab, SoiT Sci. and Plant Analysis, 8 (3), 195-207

22. L.0. Tiffin, Plant Physiol., 48, p. 273-277 (1971)

23. A.M. Ure \& J.R. Bacon, Analyst, Vol. 103, p. 807-822 (1978)

24. P. Valenta, e.a., Z. Anal. Chem., 285, p. 25-34 (1977)

25. M. Verloo \& A. Cottenie, Pedologie, 22, p. 174-184 (1972) 